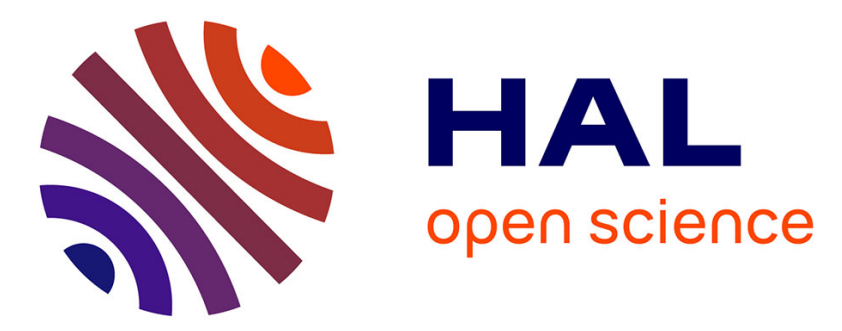

\title{
Electrical resistivity tomography (ERT) of a coastal carbonate aquifer (Port-Miou, SE France)
}

Aurélie Tassy, M Maxwell, Jean Borgomano, Bruno Arfib, François Fournier, Eric Gilli, Yves Guglielmi

\section{- To cite this version:}

Aurélie Tassy, M Maxwell, Jean Borgomano, Bruno Arfib, François Fournier, et al.. Electrical resistivity tomography (ERT) of a coastal carbonate aquifer (Port-Miou, SE France). Environmental Earth Sciences, 2014, 71 (2), pp.601-608. hal-01457507

\section{HAL Id: hal-01457507 https://hal.science/hal-01457507}

Submitted on 27 May 2021

HAL is a multi-disciplinary open access archive for the deposit and dissemination of scientific research documents, whether they are published or not. The documents may come from teaching and research institutions in France or abroad, or from public or private research centers.
L'archive ouverte pluridisciplinaire HAL, est destinée au dépôt et à la diffusion de documents scientifiques de niveau recherche, publiés ou non, émanant des établissements d'enseignement et de recherche français ou étrangers, des laboratoires publics ou privés. 


\title{
Electrical resistivity tomography (ERT) of a coastal carbonate aquifer (Port-Miou, SE France)
}

\author{
A. Tassy $\cdot$ M. Maxwell $\cdot$ J. Borgomano • \\ B. Arfib · F. Fournier $\cdot$ E. Gilli $\cdot$ Y. Guglielmi
}

Received: 29 August 2013/Accepted: 6 September 2013/Published online: 22 September 2013

(C) Springer-Verlag Berlin Heidelberg 2013

\begin{abstract}
As part of a larger regional research program "KarstEAU", the authors have applied electrical resistivity tomography (ERT) techniques to characterize heterogeneities in the Port-Miou coastal karst aquifer (Cassis, SE France). Field surveys were carried out on intensely fractured and karstified Urgonian carbonates. Extensive research has characterized macro- and micro-scale geology of the Port-Miou area and particularly underground waterfilled conduits and fault/fracture and karst systems within a former quarry. The authors applied 2D ERT along two surface profiles of length 420 and 595 m to test capability for delineating subsurface conduits and possibly relationship between conduit and fault/fracture/karst orientation;
\end{abstract}

\author{
A. Tassy $(\bowtie) \cdot$ B. Arfib · F. Fournier · Y. Guglielmi \\ CEREGE, Aix-Marseille Université, Case 67, 3 place Victor \\ Hugo, 13003 Marseille, France \\ e-mail: auretassy@gmail.com \\ B. Arfib \\ e-mail: arfib@cerege.fr \\ F. Fournier \\ e-mail: fournier@cerege.fr \\ Y. Guglielmi \\ e-mail: guglielmi@cerege.fr \\ M. Maxwell \\ Golder Associates, Burnaby, BC, Canada \\ e-mail: Michael_Maxwell@golder.com \\ J. Borgomano \\ Total CSTJF, 64000 Pau, France \\ e-mail: jean.borgomano@total.com \\ E. Gilli \\ UMR 6012 "ESPACE” Université de Nice Sophia-Antipolis, 98 \\ boulevard Édouard Herriot, BP 209, 06204 Nice Cedex, France \\ e-mail: e.gilli@wanadoo.fr
}

and 3D ERT with a dense 120 electrode array at $1 \mathrm{~m}$ spacing $(11 \times 10 \mathrm{~m})$ was applied over an area of the quarry that had been profiled using $3 \mathrm{D}$ georadar and which has had intensive nearby structural geological interpretation. The 2D profiling imaged several underground conduits at depths to $>50 \mathrm{~m}$ below ground surface and below sea level, including possibly the main Port Miou submarine spring and smaller springs. The $2 \mathrm{D}$ profiling within the quarry provided a better understanding of the connectivity between major fractures and faults on the quarry walls and secondary springs along the coast supporting flow of the secondary springs along interpreted fracture orientations. In addition, 2D inversion-derived conductivity models indicate that high resistivity zones above sea-level are associated with non-saturated zones and low resistivity anomalies in the non-saturated zone are associated with residual clays in paleokarsts. A partitioned lower resistivity zone below sea-level can be associated with a higher porosity/permeability zone with fractures and karstic features. Inversion models of the dense 3D ERT data indicate a higher resistivity volume within the larger surveyed block. The survey characterized the non-saturated zone and the ERT resistivities are correlated with karst features interpreted by $3 \mathrm{D}$ georadar and visible in the inferior wall of the quarry.

Keywords Underground karst network - Electrical resistivity tomography - Port Miou submarine spring (Cassis, SE France)

\section{Introduction}

Coastal freshwater aquifers are strategic resources that provide drinking water for approximately $70 \%$ of the 
world's population (Darnault and Godinez 2008), and karst aquifers provide freshwater to approximately $25 \%$ of the world population (Ford and Williams 2007). The sensitivity of these aquifers to human activity such as overextraction of groundwater increases the risk of seawater intrusion. The resulting critical management of this resource relies on a comprehensive knowledge and realistic conceptual model of this system. In sedimentary granular reservoirs, dominated by relatively homogeneous matrix porosity, the physics of seawater intrusion is well understood and fresh-saline interface can be interpolated from a reduced number of well monitoring and modeled on the basis of the Ghyben-Herzberg relationship. In karstic fractured-porous reservoirs, seawater intrusion is controlled by the complex architecture of the porosity network, mainly the spatial relationship between the karstic conduits and the hosting carbonate rock that can be fractured, porous or completely tight. In such cases, near surface water sampling might not be always representative of the overall aquifer, whereas hydrodynamics and numerical modeling are more complex. Near surface imaging of heterogeneous karstic reservoirs and fluids can significantly improve the understanding and models of the reservoir architecture and the fluid dynamics. Early geophysical investigations of the Port-Miou conduit (Fig. 1) were carried out in 1964 (Cornet et al. 1964) for hydraulic research by means of grounding, electromagnetic methods or resistivity. Electromagnetic method was the only one recording a signal above the intersecting shaft that had been placed $700 \mathrm{~m}$ from the outlet. Today, developments in inversion modeling of ERT data provide a valuable tool for delineating geological structures in surface and underground environments (Eso et al. 2006). In the present study electrical resistivity imaging techniques have been applied to characterize the coastal karst aquifer in the area of the Port Miou submarine spring (Cassis, SE France) as a contribution to a larger regional research program "KarstEAU".

\section{Geological characteristics of the carbonate aquifer}

The study area is part of the coast of Provence (SE France, Fig. 1) along the Mediterranean Sea. It belongs to the western part of the tectono-stratigraphic Beausset unit
Fig. 1 Location of the study area. The 2D and 3D ERT surveys are shown in red. The blue arrow locates the explored karstic conduit. The blue circles indicate coastal springs. Geological sections $\mathrm{AB}$ and $\mathrm{CD}$ are reported on the map

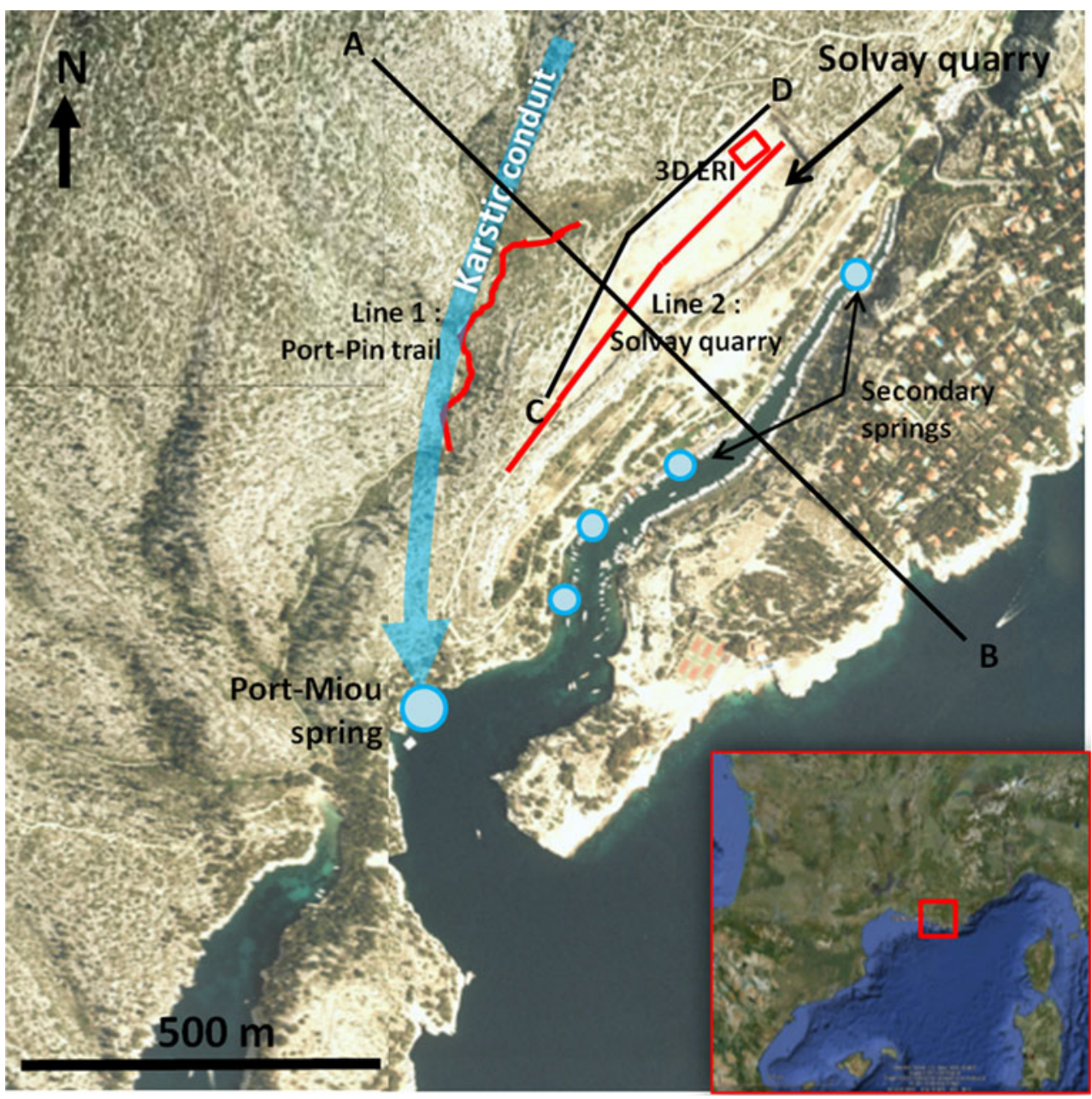


(Philip 1972; Floquet and Hennuy 2003). The Beausset unit is a $650 \mathrm{~km}^{2}$ area syncline composed of sedimentary terrains from Lower Jurassic to Upper Cretaceous. In the Western part of this unit, the Port-Miou spring is the outlet of a pluri-kilometric karst system that is developed in the 400-m thick fractured-porous and karstified Urgonian limestone of the French Mediterranean coastline (Martel 1907). The coastal spring is subjected to salt water contamination. The main karstic conduit extends approximately horizontally over 2,000 $\mathrm{m}$ with an average diameter of $20 \mathrm{~m}$. The Port-Miou site is of particular interest as a dam was built in the 1970s across the conduit, $500 \mathrm{~m}$ upstream from the coast, and $50 \mathrm{~m}$ below ground surface (Potie and Ricour 1974). Access to the karst is possible by a vertical shaft that was built to connect to the dam. Electrical properties of the brackish water of the spring are of 4,000-24,000 $\mu \mathrm{S} / \mathrm{cm}$ (Tassy et al. 2010), which is equivalent to a resistivity of $2.4-0.4 \Omega-\mathrm{m}$ (reciprocal of conductivity). Minor springs with similar physical and chemical properties as Port-Miou spring are active on the nearby coastline along a NE-SW direction (Fig. 1).
The Solvay quarry, in the Port-Miou area, exhibits abundant fractures and karstic carbonates and has been the subject of numerous sedimentology and structural studies (Masse et al. 2003; Jayet 2009; Lamarche et al. 2010; Pomar 2010). This outcrop consists of two quarry levels oriented NE-SW (Figs. 1 and 2). The Urgonian carbonates are divided into five major stratigraphic units, based on facies associations and bedding characteristics (Masse et al. 2003), and are characterized by minus-fracture matrix porosity sensu stricto $<1.8 \%$ (Pomar 2010). The quarry is located between structural ramps in a flat area with minor folds (Lamarche et al. 2010). The carbonate strata, inside and around the quarry, have experienced mostly smallscale brittle deformations. Outcrop observations indicate the frequent occurrences of fractures and faults at different scales: from bedding scale (strata-bound fractures) to the entire outcrop scale (fault). Most fractures are solutionenhanced, and are associated to karstic features (Fig. 3). Different sizes and shapes of these karstic features are visible along the quarry walls and a typology of this karst is proposed by Pomar (2010). Five shapes with different sizes

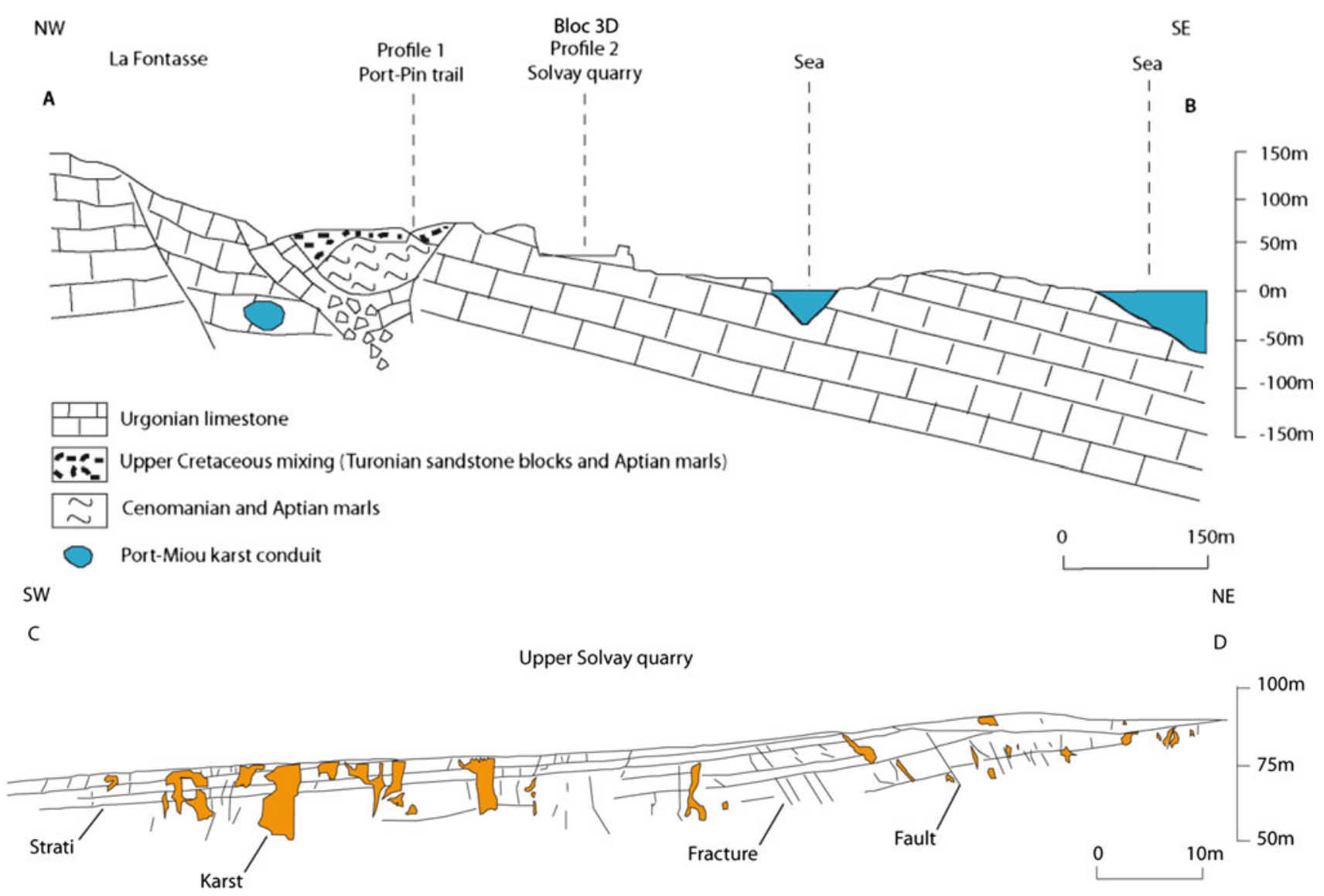

Fig. 2 Geological sections of the experimental site. Section AB is NW-SE and crosses the karstic conduit and Profiles 1 and 2. A probable karstic collapse with marly limestone fillings is located above the conduit. Section CD is SW-NE and represents the upper wall of the Solvay quarry, showing dense fracturation and karstification in the urgonian limestones 

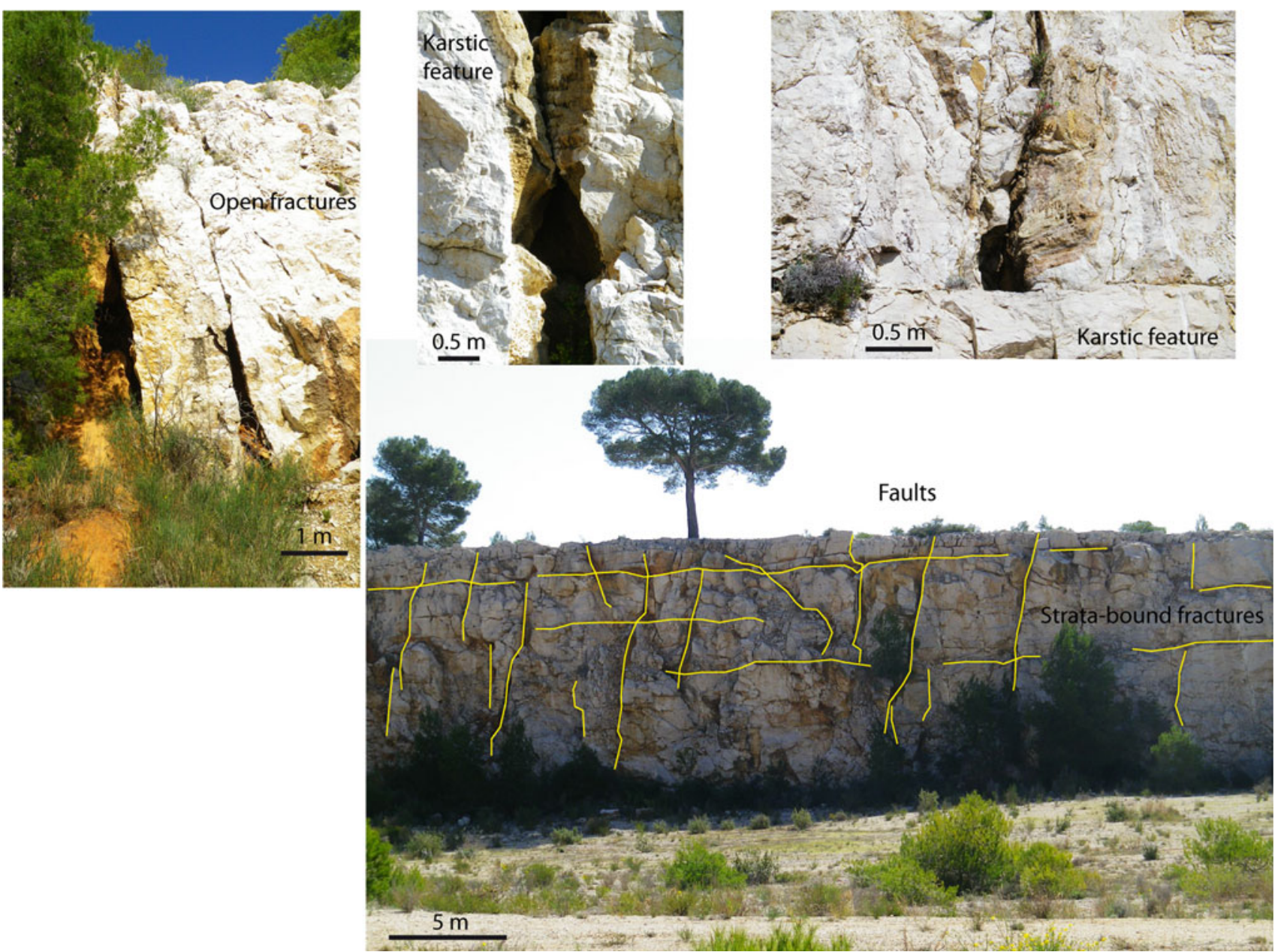

Fig. 3 Geological context of the Port-Miou Calanque. The carbonate strata have recorded brittle deformations. Outcrop observations indicate the frequent occurrences of fractures, faults and karstic features at different scales: from bedding scale to the entire outcrop scale

are described on the quarry walls: lenticular-shape, round, triangle-shape, horizontal, and large karst with speleothems. In the area, karsts develop in relatively homogenous tight limestone of the Urgonian platform (Masse et al. 2003); however, the karstic space can be empty, filled with terra-rossa or transported albian marls. Large-scale geological sections across the experimental site were interpreted and show the carbonate rock heterogeneities at different scales (Fig. 2). Section AB is NW-SE from $\mathrm{La}$ Fontasse area to the sea and cuts through the Port-Miou karstic conduit, the ERT profile 1 in Port-Pin trail and 2 in Solvay quarry, the sea in the Calanque, and the open sea. The main part of the outcrop is formed by Urgonian limestone strata gently dipping to the SE. In the La Fontasse area, two decametric heterogeneities are visible: (1) the Port-Miou karstic conduit, which can be assimilated to a $20 \mathrm{~m}$ diameter water-filled cylinder surrounded by carbonates; and (2) a marly limestone infilling a probable karstic collapse, located above the conduit. Section CD is a SW-NE representation of the upper quarry wall. Larger- scale heterogeneities are visible, with metric to decametric fractures and karst features and no spatial correlation.

\section{Materials and methods}

Because of its sensitivity to water and clay contents (Revil et al. 2002), ERT is currently considered as an efficient tool for revealing fractures and karstified zones characterized by low electrical resistivity values. ERT was applied to characterize heterogeneities in the Port-Miou coastal karst aquifer above the Port Miou main conduit and in the Solvay Quarry. In particular, ERT was used in anticipation of imaging the main karstic conduits and secondary springs within the aquifer, and the saltwaterfreshwater interface geometry. In addition, high density 3D ERT imaging was applied in a volume over an area of the quarry that had been profiled using 3D georadar and in proximity to the area of intensive structural geological interpretation noted above. 


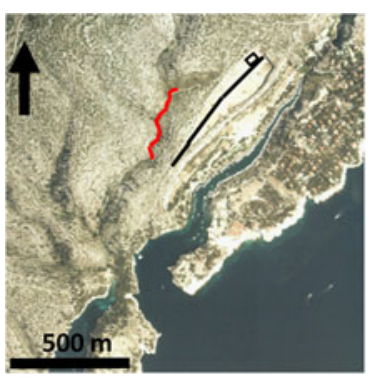

Profile 1: Port Pin Trail

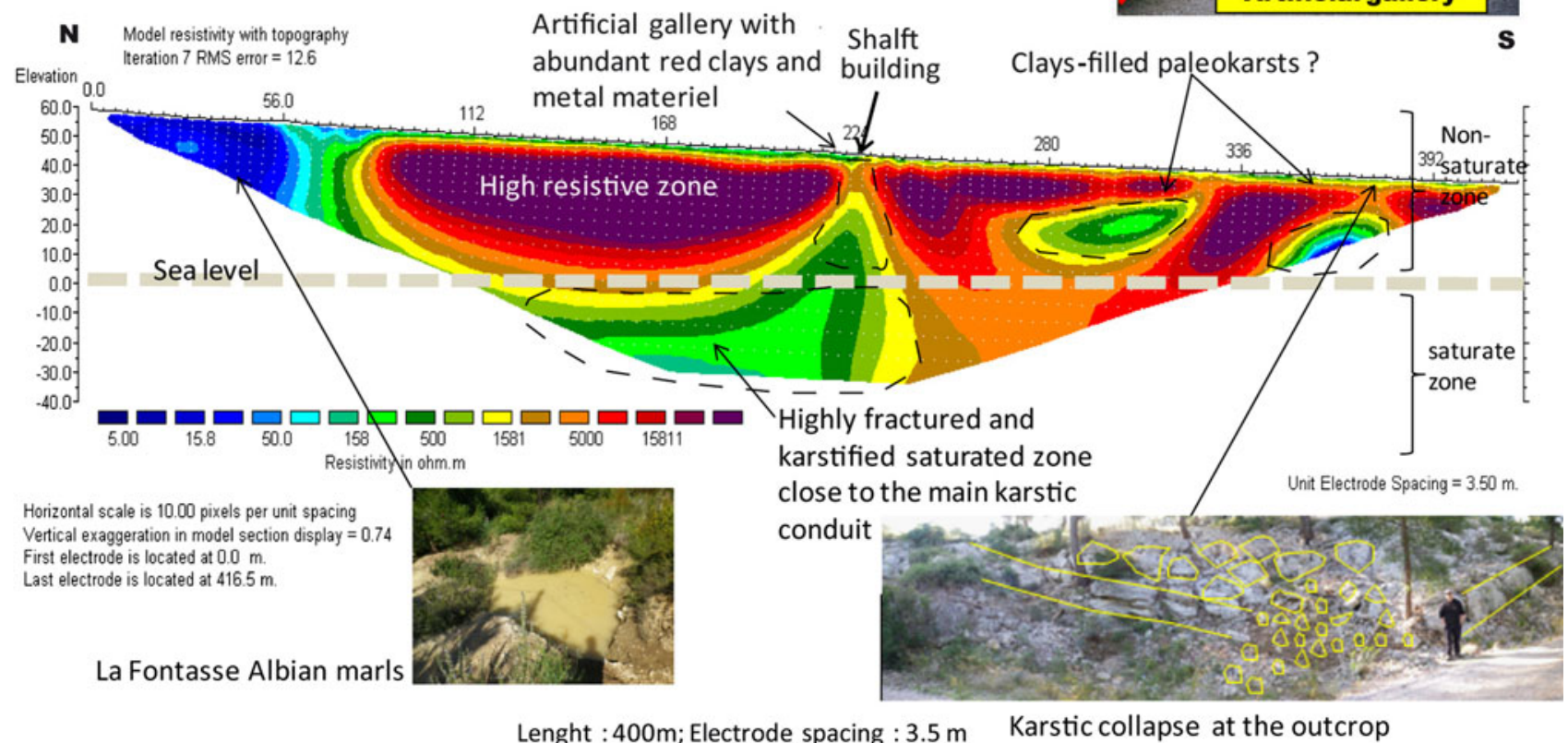

Fig. 4 N-S interpreted ERT profile along Port-Pin trail. Sea level is projected on the profiles

Two 2D survey lines were profiled using Wenner-Schlumberger and dipole-dipole arrays. The dipole-dipole data were noisy and only the Wenner-Schlumberger data were used in the study. Profile 1 was acquired along the Port-Pin trail with 120 electrodes placed at $3.5 \mathrm{~m}$ spacing for a total length of $416.5 \mathrm{~m}$. The profiled section of the trail passed within approximately $8 \mathrm{~m}$ of the shaft head over the karstic conduit. This line had gentle topography and followed the relatively gentle road meanders as electrode placement was relatively simple within the road footprint (Figs. 1 and 2). Profile 2 was located in the Solvay Quarry with 120 electrodes placed at $5 \mathrm{~m}$ spacing for a total length of $595 \mathrm{~m}$. The line extended from a high point to the south down a gentle ramp and onto the relatively flat quarry floor, which consisted of limestone bedrock partly covered with gravels from the quarry exploitation. The quarry profile is situated between the main conduit and many secondary springs along the coastline (Figs. 1 and 2).

The electrodes were placed either by hammering into the loose soil or by drilling into the soft rock where necessary. Ocean water was used to enhance electrode contact resistances all of which were measured to be of similar order between several hundred $\Omega-\mathrm{m}$ to several thousand $\Omega-\mathrm{m}$.
A dense 3D ERT survey was acquired in the Solvay quarry by placing 120 electrodes at $1-\mathrm{m}$ spacing in a grid of $11 \times 9 \mathrm{~m}(12 \times 10$ electrodes $)($ Fig. 1). Dipole-dipole and pole-pole data were collected. The results of both datatypes were similar and the results reported here used the pole-pole data because of its deeper penetration. A 3D georadar survey had previously targetted a larger volume, which included the ERT footprint for the purpose of imaging fractures and karst (Pomar 2010). The 120 electrodes were placed by drilling $4-\mathrm{cm}$ deep holes and the placements were again watered lightly with ocean water to reduce contact resistance.

An IRIS120 Syscal system was used to collect the 2D and 3D data. The data were of good quality and were modeled using Loke's RES2DINV and RES3DINV commercially available software. The models are provided as color-contoured representations of subsurface resistivity variations. For 2D profiles, low resistivity/high conductivity zones are represented by blue-green and high resistivity/low conductivity zones by purple-red. Yellow-brown colors are transitional. The highly resistive subsurface in the 3D model has resistive material shown in red with highly resistive material shown in purple-white. 

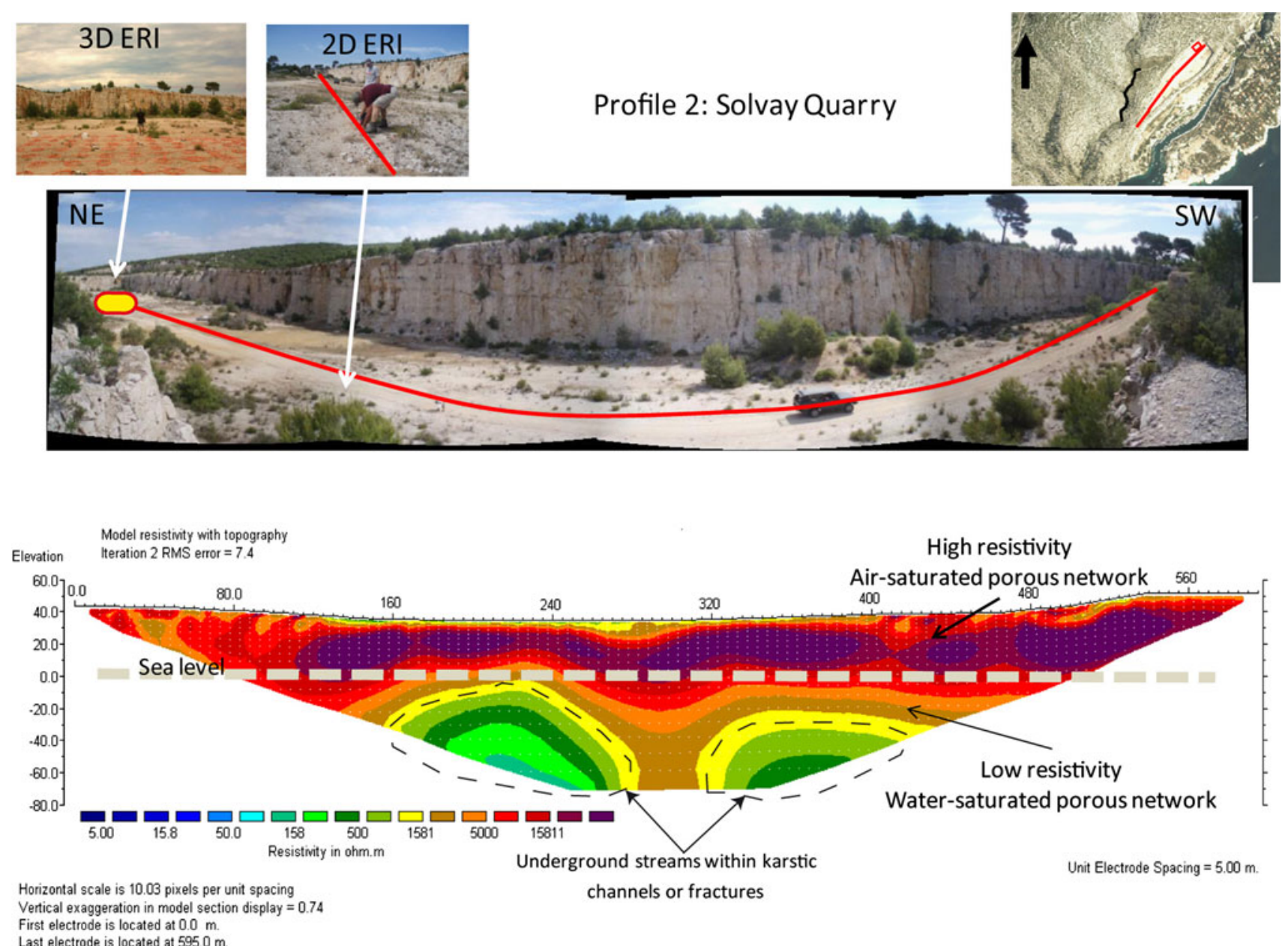

Fig. 5 NE-SW interpreted ERT profile in Solvay Quarry. Sea level is projected on the profiles

The interpretation of the ERT presented here is semiquantitative and not calibrated with lab measurements of the different materials. The overall resistivity variations were highlighted and related to observations of the different materials and structural geology. The material resistivity values vary based on a combination of parameters: the mineralogy of the rock (limestone or claystone), the type of porosity network (karst, fractures, mixed karst and fractures and tight non-fractured rock), and the nature of porosity filling (air, freshwater, saltwater, claystone). With the 3.5 and $5-\mathrm{m}$ electrode spacings, modeled cell sizes are in the same order so that typically small-scale heterogeneities, such as small air-filled fractures, are averaged with the surrounding rock. However, in situations where high resistivity contrasts are present, such as highly conductive saline water or clays within relatively resistive rock, the area/volume of the feature typically will appear larger in the colour-contoured model presentation.

\section{Results}

For the two 2D profiles, inversion-derived conductivity models of the data indicate resistivity variations from $10-10^{4} \Omega \mathrm{m}$ (Figs. 4 and 5). A higher resistivity zone above sea-level can be associated with a non-saturated zone, whereas a distinct isolated lower resistivity zone under sea-level can be associated with a higher porosity/ permeability zone with fractures and karstic features in the saturated zone.

The Port-Pin 2D line extends over $400 \mathrm{~m}$ and images the rock to $80 \mathrm{~m}$ depth (Fig. 4). Electrode spacing was $3.5 \mathrm{~m}$. Three significant low resistivity/high conductivity anomalies are present. The shallow conductive zone to the North between approximately $0-70 \mathrm{~m}$ along profile was interpreted as being related to a freshwater seep area in $\mathrm{La}$ Fontasse shales, which are a mixture of Albian, Cenomanian and Turonian filling of a karstic collapse (Daouddi 2009). 


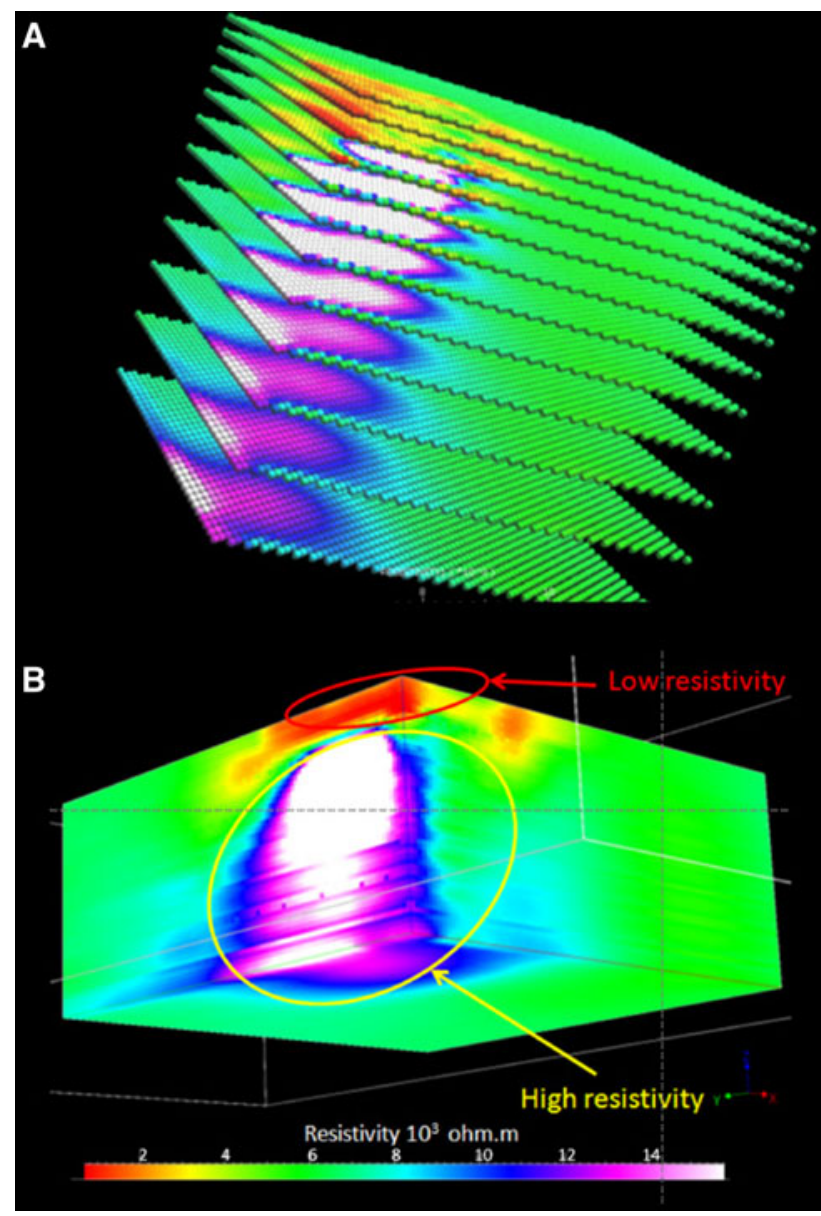

Fig. 6 a Point set of 3D resistivity values measured on the Solvay quarry. b 3D modeling of ERT cube in the Solvay quarry. Dimensions of the ERT cube are $30 \times 30 \times 15 \mathrm{~m}(x y z)$ with the surveyed area $11 \times 9 \mathrm{~m}$

There are two shallow low resistivity features to the south. The feature, centered at approximately $364 \mathrm{~m}$, is located under a karstic collapse, clearly visible on the outcrop above the profile as highlighted in Fig. 4. Observations in the whole study area show that paleokarsts are often filled with terra-rossa, transported albian marls, or are unfilled. The low resistivity values measured (under $50 \Omega \mathrm{m}$ ) combined with the observed karstic collapse just above, can be interpreted as clay-filled paleokarst. The final low resistivity feature is at the middle of the line and indicates as a low resistivity zone (100-1,500 $\Omega \mathrm{m}$ ) which enlarges downwards. This feature is in the area of the shaft that was built to access the Port-Miou artificial gallery entrance. Although metal associated with the shaft may cause some interference, the size and depth of the conductive anomaly and the results for the Solvay quarry line suggest that the feature can be interpreted as a highly fractured and karstified saturated zone situated near the main karstic conduit and possibly detecting this conduit.

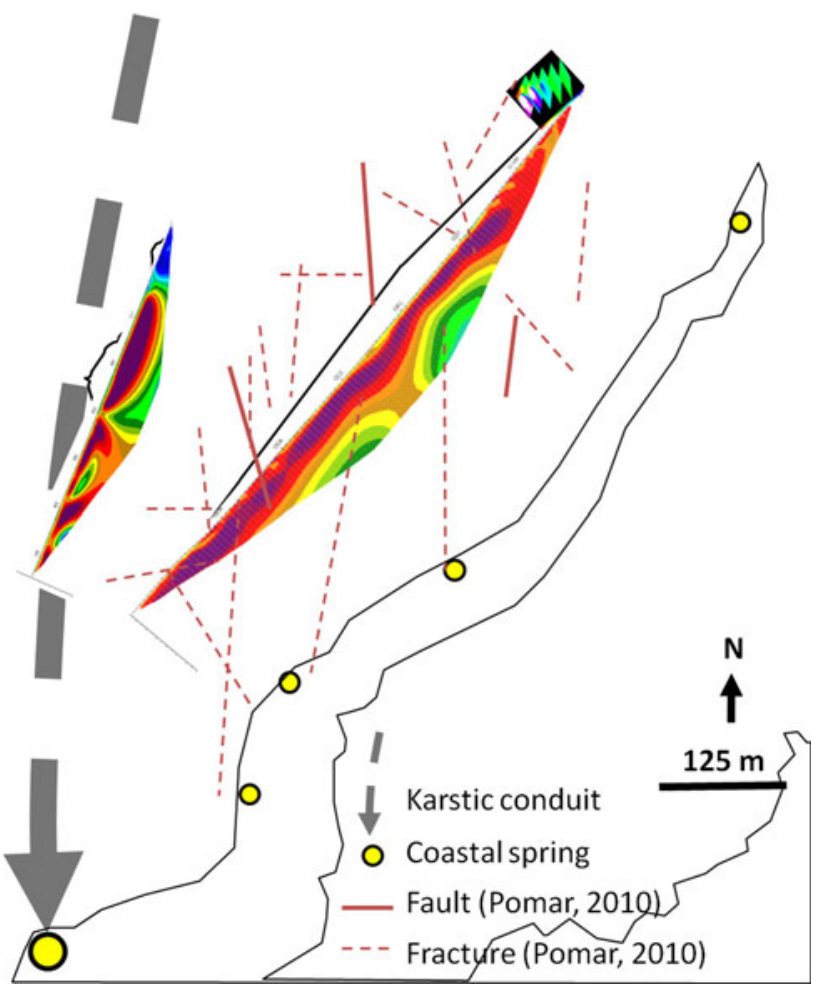

Fig. 7 Location of ERT profiles, karstic conduit, fractures in the quarry and coastal springs. Major fractures and secondary springs are associated with electrical resistivity anomalies in the surveyed area along the coast of Port-Miou

The highly resistive zones that are present correspond to dry, shallow soil and the resistive host rock.

The Solvay quarry 2D line extends over $600 \mathrm{~m}$ in length and images the rock to approximately a 100-m depth (Fig. 5). Electrode spacing was $5 \mathrm{~m}$. Results show a relatively flat resistivity contrast from high resistivity above sea level to very low resistivity below sea-level sea level that could be related to the salt-water wedge. Piezometric level given by the flat contrast on the profile shows in fact a $20 \mathrm{~m}$ variation in height from NE to SW. There are two deep conductive features below sea level. These features are slightly different in that the northern one is wider and more conductive suggesting that it is either shallower or larger. The southern feature may be at the limit of the depth detection of the ERI profile. These features were interpreted as underground streams within karstic channels or fractures that are consistent with secondary springs observed on the field (Figs. 1 and 7). A fracture study in the quarry shows that the streams are connected to N-S faults (Jayet 2009; Lamarche et al. 2010; Pomar 2010). The ERI profile also reveals that the upper zone is non-saturated and that karstic voids and open fractures observed on the quarry walls are air saturated.

The 3D ERI was completed within this probable air-saturated zone in the northern part of the quarry. The modeled results of the $11 \times 9 \mathrm{~m}$ surface grid were represented within 
the larger modeled resistivity cube $(30 \times 30 \times 15 \mathrm{~m})$ as illustrated in Fig. 6a, b. The electrode spacing was $1 \mathrm{~m}$. Very high resistivity values are measured, from $10^{3}-10^{4} \Omega \mathrm{m}$ corresponding to the top of the non-saturated zone on the quarry $2 \mathrm{D}$ profile. These overall high resistivity values correspond to the expected range of carbonate resistivity and the modeled results imaged significant contrasts within the rock. A small zone of relatively lower resistivity is imaged on top of the southwestern corner of the cube (red zone as marked in Fig. 6b). Under this zone, a mushroom-like anomaly of very high resistivity extends to the limit of penetration. GPR interpretation (Pomar 2010) shows a concentration of large fractures and karstic features at this location. According to the spatial correlation between the GPR and the ERT results, this mushroom-like anomaly is interpreted as decametric airsaturated karstic void. Such karstic voids occur in the quarry; for example, one in the lower wall was used as a natural conduit for transporting ballast to the lower level at the time of the quarry exploitation. In addition, one important result is the spatial connection between major fractures in the quarry (Pomar 2010), resistivity anomalies on profile 2, and minor submarine springs along the coastline (Fig. 7). Spring water is sourced from the main karstic conduit situated upstream and is deviated by an open fracture and karst network before the main outlet.

\section{Conclusion}

The integration of geophysics and outcrop geology is useful to characterize underground heterogeneities in complex karstic systems. This ERT survey images the large-scale and spatially correlated resistivity contrasts and heterogeneities, which can be interpreted in terms of fluid and reservoir. The 2D lines imaged a piezometric level, near sea level, within fractured carbonate based on the higher conductivity of saline water compared to air and limestone. Individual karst and fracture corridors, filled with air, clay or water, have been detected and compared to analogue objects on the outcrop. The higher conductive anomalies imaged in the $2 \mathrm{D}$ profiles have revealed the presence of fracture corridors linking the Port Miou conduit and the secondary coastal springs. In the relatively resistive formation within the quarry, 3D ERT delineated resistivity contrasts as represented by the mushroom-like resistive anomaly interpreted as an air-filled cavity above the water table.

ERT surveys can be used to map the underground karst network from the surface. The authors anticipate that in future multiple 2D profiles and larger volume 3D surveys will be used to expand the understanding of the karst network. Further work also will integrate nearby offshore high resolution seismic and possible calibration wells.
Acknowledgments This work is part of KarstEau project, funded by the "Agence de l'Eau Rhône-Méditerranée-Corse", the "Conseil Général du Var", the "Conseil Général des Bouches-du-Rhône", and the "Région Provence-Alpes-Côte d'Azur". Authors are grateful to Jan Borgomano, Clément Ciocca, Loïc Pantaine, Thomas Maggiore and Michel Tassy for the collaboration in the ERI surveys. Thanks to the Cassis town hall for facilitating the activities in the study area.

\section{References}

Cornet G, Durozoy G, Gouvernet Cl, Munck F (1964) La source sousmarine de Port-Miou (Calanques de Cassis) Etude par prospection géophysique. Livret-guide hydrogéologique, 8-9 et 10 Juin 1964. BRGM

Daouddi B (2009) Formations "post-urgoniennes" dans deux depressions du Massif des Calanques (de Marseille à Cassis). AixMarseille Université, Mémoire de Master

Darnault CJG, Godinez IG (2008) Overexploitation and contamination of shared groundwater resources. In: Darnault (ed) Coastal aquifers and saltwater intrusion. Springer Science + Business Media B.V, Dordrecht

Eso R, Oldenburg D, Maxwell M (2006) Application of 3D electrical resistivity imaging in an underground potash mine SEG Expanded Abstracts 25:629

Floquet M, Hennuy J (2003) Evolutionary gravity flow deposits in the Middle Turonian-Early Coniacian Southern Provence Basin (SE France): origins and depositional processes. In: Locat J, Mienert $\mathrm{J}$ (eds) Advances in natural and technological hazards research, submarine mass movements and their consequences, vol 9. Kluwer Academic Publishers Book Series, Dordrecht, pp 417-424

Ford DC, Williams PW (2007) Karst geomorphology and hydrology. Chapman and Hall, New York, $601 \mathrm{p}$

Jayet $\mathrm{O}(2009)$ Les faciès de fracturation dans les roches carbonatées : typologie, contrôles sédimentologiques et propriétés pétrophysiques (Crétacé inf. Bassin Sud Provençal). Mémoire de Master 2, Aix-Marseille Université, France

Lamarche J, Jayet O, Lavenu A, Gauthier B, Guglielmi Y, Demory F, Masse JP, Marie L (2010) Mechanostratigraphy and fracture facies in lower Cretaceous carbonates of Provence (SE-France): EGU Meeting

Martel EA (1907) Sur un projet d'utilisation de la source sous-marine de Port-Miou (B. du R). Annales de l'hydraulique agricole. Fasc. 36 bis

Masse JP, Fenerci M, Pernarcic I (2003) Palaeobathymetric reconstruction of peritidal carbonates late barremian, urgonian, sequences of provence (SE France): palaeogeography. Palaeoclimatoly. Palaeoecology 200:65-81

Philip J (1972) Paléoécologie des formations à rudistes du Crétacé supérieur - L'exemple du Sud-Est de la France. Palaeogeogr Palaeoclimatol Palaeoecol 12(3):205-222

Pomar K (2010) Visualization and quantification of fractures and karst in Cretaceous carbonates, Cassis. Master of Sciences, University of Miami, France, 105 p

Potie L, Ricour J (1974) Etudes et captage de résurgences d'eau douce sous-marines. Ressources en eau pp 5-26

Revil A, Hermitte D, Spangenberg E, Cochemè JJ (2002) Electrical properties of zeolitized volcaniclastic materials. J Geophys Res 107(B8):2168. doi:10.1029/2001JB000599

Tassy A, Arfib B, Gilli E (2010) Access to coastal karst resources through a salinity study during an exceptional high-water event: the case of Port-Miou (SE France). Advances in Research in Karst Media. IVe Symposium on karst, Malaga, pp 49-55 